\title{
DISAMBIGUATION OF NEUTRALIZED FORMS IN TWO CROATIAN VARIETIES ${ }^{1}$
}

\section{Introduction}

A type of northwestern Croatian pronunciation, also known as the Kajkavian accent, was compared with the standard Croatian pronunciation with respect to the strategies used to disambiguate neutralized final obstruents. The two varieties differ in that the former is characterized by the phonological rule of Final Devoicing, where word-final obstruents are realized as voiceless:

$[+$ obstr. $] \rightarrow[-$ voice $] /$

In the latter variety, however, devoicing occurs only as an assimilation process before voiceless environment:

$[+$ obstr. $] \longrightarrow[\alpha$ voice $] / \longrightarrow[+ \text { obstr. } \alpha \text { voice }]^{2}$

The aim of the comparison was twofold. In the first place, the research was conducted to show how Eliasson's (1991) hypothesis about a cognitive calculus that is complementary to phonological rules applies to these two varieties. In other words, we wanted to see whether the strategy of disambiguation of surface voiceless obstruents is that of reanalyzing neutralized surface forms (e.g. brod "boat" brot) by comparing them to the form that contains relevant morphophonemic information, i.e. to that of the oblique case (gen. broda). If it turns out that this strategy is employed by the speakers of the two varieties of pronunciation, Croatian can be added to the list of languages (including Russian and Polish) for which Eliasson's hypothesis holds true.

1 This is a slightly revised version of a paper submitted to the 7th International Phonology Meeting, Krems, Austria, July 4-7, 1992. We are grateful to S. Eliasson for his comments to the original paper. The still remaining inadequancies are, of course, our own.

2 "Here the symbol " $\alpha$ " is understood to indicate that the output of the change has the same feature value ("+" or "-") as the conditioning environment (Hock, 1986). 
Another interesting issue that arises in connection with the reanalysis involved in disambiguation concerns the dialectological or, rather variation aspect of disambiguation. We looked at how the extent of reanalysis of surface voiceless obstruents correlates with the native variety of the speaker/listener.

\section{Procedure}

The procedure employed was a somewhat modified version of the psycholinguistic test uesd by Eliasson (1991) within a wider research project covering several languages. We used a perceptual test involving two different stimuli (one recorded by a Standard and one by a Kajkavian Croatian speaker) and two different groups of listeners (10 Standard and 10 Kajkavian listeners), i.e. four different test situations. The items for disambiguation were possible but non-existent Croatian words ending in a voiced obstruent, referring to imaginary beings or phenomena from a science-fiction story: Sened, inug, Kartiz and trab. Each item was recorded by each speaker twice at each of the following three stages: (1) in isolation; (2) in a context where it appeared in the nominative, i.e. in an environemt triggering final devoicing in the Kajkavian variant and only partial devoicing in the Standard; (3) in a context where it appears in an oblique case, i.e. in an environment where the obstruent surfaces as voiced. The listeners in the experiment correspondingly identified the four ambiguous items ("new words") in three successive stages, and at the end of the test, they were encouraged to reconsider their earlier responses and correct them if they felt correction was needed.

\section{Results}

Table (1) represents the overall extent of the identification of the ambiguous final obstreunts as voiceless. Test I covers the first two of the three stages referred to above; test II follows stage (3); the bottom row of the table represents the extent of reanalysis of the final obstruents originally perceived as voiceless. ${ }^{3}$

\begin{tabular}{|l|l|l|}
\cline { 2 - 3 } \multicolumn{1}{c|}{} & \multicolumn{2}{c|}{ PERCEIVED AS VOICELESS } \\
\cline { 2 - 3 } \multicolumn{1}{c|}{} & Pure no & $\%$ \\
\hline test I & 129 & 100 \\
test II & 24 & 18,60 \\
reanalzsis & 105 & 81,40 \\
\hline
\end{tabular}

Table (1): Overall perception of stem-final obstruents as voiceless

3 No objective tests were made of the voiceless/voiced production of the words, so the entire test is based on subjective perception of the informants. 
The above results show that in Croatian obstruents in stem/word-final position are generally perceived as voiceless. Like in Polish and Russian, reanalysis of the tentatively established lexicon on the basis of the morphosyntactic information obtained from the context takes place in a significant number of cases. This is to say that speakers of Croatian first rely on their perception of sound in various contexts, which experience is then reconsidered in view of the morphosyntactic rules and reanalyzed drawing on both system and perception.

The following two tables, (2) and (3), show how the extent of identification of the final obstruent as voiceless depends on the variant pronunciation of the speaker (goal no. 2):

\begin{tabular}{|l|l|l|l|l|l|l|}
\cline { 2 - 7 } \multicolumn{1}{c|}{} & \multicolumn{2}{c|}{ KAJK. LISTENERS } & \multicolumn{2}{c|}{ ST. LISTENERS } & \multicolumn{2}{c|}{ TOTAL } \\
\cline { 2 - 7 } \multicolumn{1}{c|}{} & Pure no. & $\%$ & Pure no. & $\%$ & Pure no. & $\%$ \\
\hline test I & 40 & 100 & 40 & 100 & 80 & 100 \\
test II & 6 & 15 & 9 & 22,5 & 15 & 18,75 \\
reanal. & 34 & 85 & 31 & 77,5 & 65 & 81,25 \\
\hline
\end{tabular}

Table (2): Kajkavian speaker

\begin{tabular}{|l|l|l|l|l|l|l|}
\cline { 2 - 7 } \multicolumn{1}{c|}{} & \multicolumn{2}{c|}{ KAJK. LISTENERS } & \multicolumn{2}{c|}{ ST. LISTENERS } & \multicolumn{2}{c|}{ TOTAL } \\
\cline { 2 - 7 } \multicolumn{1}{c|}{} & Pure no. & $\%$ & Pure no. & $\%$ & Pure no. & $\%$ \\
\hline test I & 30 & 100 & 19 & 100 & 49 & 100 \\
test II & 4 & 13,3 & 5 & 26,3 & 9 & 18,4 \\
reanal. & 26 & 86,7 & 14 & 73,7 & 40 & 81,6 \\
\hline
\end{tabular}

Table (3): Standard speaker

It is indicative that final devoicing was perceived in the speech of the Kajkavian in $100 \%$ cases by both groups of listeners. This proves the existence of the corresponding phonological rule in the Kajkavian variety of Croatian. In the Standard variety, however, the smaller extent of identification of these segments as voiceless in the corresponding environment can be accounted for by the lack of final devoicing as a phonological rule. It should also be noted that there was no significant difference in the reanalysis patterns for the two speakers.

The following tables, (4) and (5), show how the identification of final obstruents as voiceless depends on the native pronunciation of the listeners:

\begin{tabular}{|l|l|l|l|l|l|l|}
\cline { 2 - 7 } \multicolumn{1}{c|}{} & \multicolumn{2}{c|}{ KAJK. STIMULI } & \multicolumn{2}{c|}{ ST. STIMULI } & \multicolumn{2}{c|}{ TOTAL } \\
\cline { 2 - 7 } \multicolumn{1}{c|}{} & Pure no. & $\%$ & Pure no. & $\%$ & Pure no. & $\%$ \\
\hline test I & 40 & 100 & 19 & 100 & 59 & 100 \\
test II & 9 & 22 & 5 & 26 & 14 & 23,7 \\
reanal. & 34 & 85 & 26 & 87 & 60 & 85,7 \\
\hline
\end{tabular}

Table (4): Kajkavian listeners 


\begin{tabular}{|l|l|l|l|l|l|l|}
\multicolumn{1}{c|}{} & \multicolumn{2}{c|}{ KAJK. STIMULI } & \multicolumn{2}{c|}{ ST. STIMULI } & \multicolumn{2}{c|}{ TOTAL } \\
\cline { 2 - 7 } \multicolumn{1}{c|}{} & Pure no. & $\%$ & Pure no. & $\%$ & Pure no. & $\%$ \\
\hline test I & 40 & 100 & 19 & 100 & 59 & 100 \\
test II & 9 & 22 & 5 & 26 & 14 & 23,7 \\
reanal. & 31 & 78 & 14 & 74 & 45 & 76,3 \\
\hline
\end{tabular}

Table (5): Standard listeners

It can be observed that the native variety of pronunciation of the listeners plays a greater role than the native pronunciation of the speaker in the reanalysis patterns, which points to the influence the phonological matrix acquired first has on future cognition processes. This fact has several implications, one of them being that speech production cannot be objectively measured by speech perception. By extension it also corroborates the validity of distinguishing between the speaker's and listener's grammars. It further gives some support to the hypothesis (Sapir-Whorf) that the (native) language system influences cognition.

These differences in the reanalysis patterns dependent on the pronunciation of speaker versus the pronunciation of listener is shown in the form of a histogram figure б):

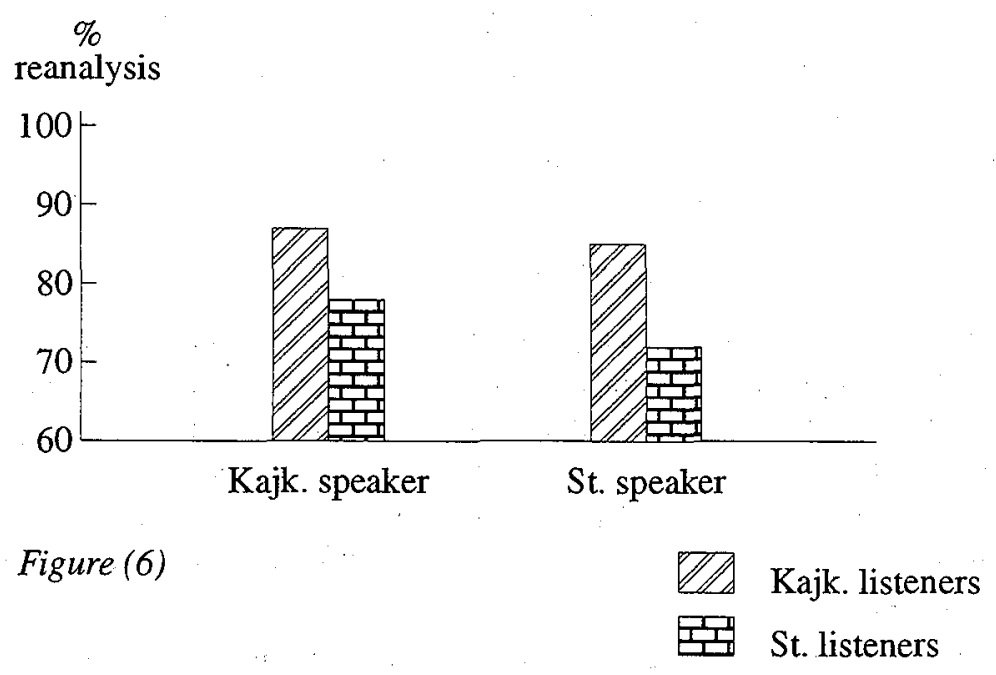

Finally, the difference between the responses by the two groups of listeners can be analyzed with respect to the number of items reanalyzed by individual subjects. The number of items reanalyzed ranged from 0 to 4 . Figure (7) shows the frequency patterns for the two groups of listeners. The rising pattern for the Kajkavian listeners v. the level pattern for the Standard listeners reflects a greater overall tendency towards reanalysis observed among the Kajkavian subjects. 


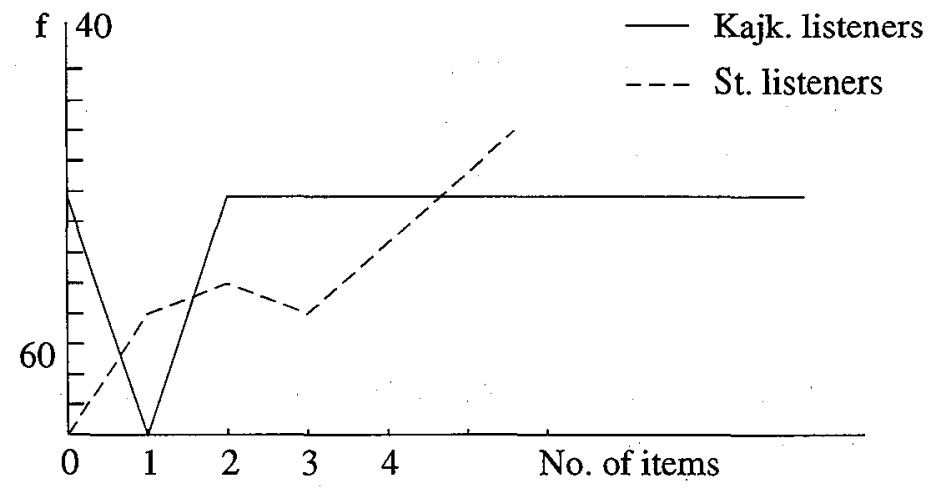

This tendency may also be the explanation for the fact that we observed several cases of hypercorrect responses by the Kajkavian listeners for items from the non-alternatig set that objectively ended in a voiceless obstruent zok analyzed as zog: plet analyzed as pled. This again points out that in the interraction of new cognitive experience and the acquired language system, the system plays a significant role in the cognitive process. Speakers of a system with word final voice neutralization will more heavily rely on the system (and its rule of devoicing voiced obsturents in non-voiced environment), than on perception. This is to say, that in doubtful cases it will be assumed that the neutralizing rule is operating. It is interesting to note that the same strategy is applied in the perception of "foreign" varieties within a linguistic continuum (or diasystem) as in the perception of a foreign linguistic system.

\section{Conclusion}

The present research shows that the hypothesis about a cognitive calculus that is supplementary to phonological rules holds true for the two observed varieties of Croatian. In addition, it turns out that the native variety of the subject plays a significant role in the reanalysis involved in disambiguation.

The present study shows that in the process of recognition and acquisition of (spoken) language there are three factors that play a part, i.e. (1) auditory perception, (2) existing lexicon, (3) a set of phonological rules. The processing of the auditory input involves repeated collation with the lexicon and phonological/grammatical rules. Thus any additions made to the lexicon are made in conformity with the system. The tests performed with speakers of two different varieties and two separate groups of listeners who are native speakers of the two varieties also point out the influence that language rules acquired first exert on the cognition of new language material. 
This lag in language processing has been noticed in contrastive studies of languages and acknowledged as a problem in foreign language learning (cf. also Eliasson \& Tubielewicz Mattson, 1992). From the same experience it can be gathered, however, that new cognitive matrices can be (and are) formed and applied in the acquisition of further new language material (e.g. in learning a third language).

\section{Reference}

Barić, Eugenia et al. (1979) PRIRUČNA GRAMATIKA HRVATSKOGA KNJǏEVNOG JEZIKA, Školska knjiga, Zagreb.

Eliasson, Stig (1991), The cognition/rule interface in phonological processing. Paper presented at the 3rd International Conference of the International Society of Applied Psycholinguistics, Toronto, July 18, 1991.

Eliasson, Stig \& Dorota Tubielewicz Mattson (1992), Cognitive processing of phonological ambiguity in second-language learning. Paper in progress.

Hock, Hans Heinrich (1986) PRINCIPLES OF HISTORICAL LINGUISTICS, Trends in Linguistics, Studies and Monographs 34. Mouton de Gruyter, Berlin-New York-Amsterdam.

Povzetek

RAZDVOUMLJENJE SOVPADLIH OBLIK V DVEH VARIANTAH HRVAŠČINE

Sestavek opisuje preizkus, $v$ katerem se dve varianti hrvaščine (knjižna in eno izmed narečij) vzporejata glede razzvenečenja zapornikov na koncu besede. Preizkus je pokazal, da velja v opazovanih variantah hrvaščine domneva o kognitivnem kalkulusu kot dodatku fonološkim pravilom. Ugotovljeno je bilo, da igra pomenljivo vlogo (pri spremenjeni razčlembi, ki spremlja razdvoumljenje razzvenečih zapornikov) poslušalčeva domača varianta. 